\title{
Marcin Serwiński
}

Wrocław University of Economics and Business

e-mail: marcin.serwinski@ue.wroc.pl

ORCID: 0000-0002-4064-3938

\section{FOLLOW-THE-SUN IS IT REALLY \\ A STRATEGY FROM THE PERSPECTIVE OF STRATEGIC MANAGEMENT?}

DOI: $10.15611 / \mathrm{pn} .2021 .2 .10$

JEL Classification: F23, L62, O32

\section{(C) 2021 Marcin Serwiński}

This work is licensed under the Creative Commons Attribution-ShareAlike 4.0 International License. To view a copy of this license, visit http://creativecommons.org/licenses/by-sa/4.0/

Quote as: Serwiński, M. (2021). Follow-the-sun is it really a strategy from the perspective of strategic management? Prace Naukowe Uniwersytetu Ekonomicznego we Wroctawiu, $65(2)$

\begin{abstract}
The article is a response to an issue, raised by Beulen (2012), related to time zone and strategy which have not been fused together in management or the outsourcing literature. "There has been some theoretical thinking on the impact of time zones on scheduling, but not on strategy" (Carmel, 2012, p. 2). The subject of the analysis is the Follow-the-Sun (FTS) strategy, which is the hardest among those taking advantage of time zone differences (cf. (Carmel \& Espinosa, 2011, p. 58). The strategy's main objective is to further increase the pace of R\&D work by using project teams dispersed in distant time zones and therefore capable of ensuring a 24-hour work cycle without the need to work at night (Serwiński, 2019a, p. 1). In turn, the main goal of the paper is to present a specific proposal for classifying the FTS strategy in strategic management.
\end{abstract}

Keywords: Follow-the-Sun, Time-to-Market, strategic management, automotive, time zones.

\section{Introduction}

Until recently, Follow-the-Sun (FTS) was understood only as a special case of Global Software Development (GSD), where software development takes place 24 hours a day in shifts, without the need to work at night (cf. Carmel, Dubinsky, \& Johnston 2008 , p. 2). With such an organisation of work, the location of individual groups of programmers at appropriate longitudes of the globe is aimed at transferring the 
developed tasks daily from the location ending a standard working day to the next location where the working day begins. The essence of FTS is to shorten Time-toMarket (TTM), defined as the period from the concept phase until the product is available for use or sale (Smith \& Reinersten, 1991).

A new direction set by the author of this paper is to use the FTS approach in automotive R\&D units, other than Software Development. The most recent conditions that determine the possibilities of this direction, as well as model proposals for the use of FTS in automotive industry are presented in the article (Serwiński, 2019b). In another publication a potential type of multi-departmental automotive R\&D units which can implement FTS (Serwiński, 2019a), was identified (in the course of empirical research).

The main purpose of this study is to present a specific proposal for classifying the FTS strategy in strategic management. Its selection, from among others, of the briefly mentioned criteria of strategy classification in the third section, was preceded by an extensive literature review on strategic management and outsourcing. In order to understand the discussed issues in the best possible way, the author selected the most important premise of the FTS approach, pointing to their convergence with the schools of strategic management that preceded them in chronological order in the second section. Up to now, the only publications presenting the characteristics of the FTS originate from the GSD area (cf. Kroll, Richardson, Prikladnicki, \& Audy, 2018, pp. 31-38). In particular, scientists and specialists from GSD have raised the issue related to time zones and strategy which have not been fused together in management or the outsourcing literature (cf. Beulen, 2012). "There has been some theoretical thinking on the impact of time zones on scheduling, but not on strategy" (Carmel, 2012 , p. 2). The validity of the scientific gap described in 2012 was also confirmed by the author as a result of the literature analysis (up to and including 2019) concerning the two mentioned fields of knowledge.

However, before reading further on, attention should be paid to the terminological dissonance in the literature related to the FTS strategy. The term that could most likely lead to confusion in defining FTS as a strategy is Round-the-Clock (RTC). This approach also exploits the difference in time zones, but in a slightly different way. Unlike complex FTS projects created using Follow-the-Sun, RTC quickly performs a one-off task, often in just a few minutes. There is therefore a slight dependency between remote locations that minimises the (typical for FTS) challenges of daily project coordination between remote units. In simpler terms, FTS means speed, and RTC is based on the use of time zones to cover 24-hour demand, for example to support so-called global helpdesks or global support centres (cf. Carmel 2012, p. 182, 2013, p. 64; Carmel, Espinosa, \& Dubinsky, 2010, pp. 6-7).

Other examples of a lack of consistency in the terminology used include describing the FTS characteristics as 24-Hour Development (cf. Doma, Gottschalk, Uehara, \& Liu, 2009; Setamanit, Wakeland, \& Raffo, 2006, 2007) or 24-Hour 
Knowledge Factory (cf. Gupta, Bondade, \& Denny, 2008; Gupta, Mattarelli, Seshasai, \& Broschak, 2009; Gupta \& Seshasai, 2007; ). However, in these cases, these names can only be treated as synonyms of FTS and therefore pose less threat to the correct understanding of the rest of the paper.

In conclusion, the FTS term is interchangeable with other types of time zone strategies and has no place in strategic management.

\section{Follow-the-Sun in selected strategic management schools}

The aforementioned literature review revealed how often the rationale for the FTS approach has found its place in different trends of strategic management. The most important premise of FTS are listed directly after the convergent characteristics of individual schools of strategic management. The following summary contains a total of ten comparisons ${ }^{1}$ of the strategic management schools vs. 'the converging FTS rationale':

1. The Planning School at its core assumes that organisations can and should shape their future in a rational and structured way by building strategic plans, often based on the extrapolation of indicators from the company's past. Creating a strategy has the character of a disciplined, mostly formalised process in the form of a document that says what, who and how a certain thing should be done, and according to the assumptions of this school is based on the perspective of the company's president (chief strategist) or, more broadly, the top management (Obłój, 2014, pp. 27-31).

Convergence with FTS: similarly, FTS implementation requires careful planning (cf. Kroll et al., 2018, p. 2). Strategic planning is indicated as one of the key factors for task allocation between remote locations (cf. Mahmood, Anwer, Niazi, Alshayeb, \& Richardson, 2017, p. 3). The opening of new units in remote locations in order to start global cooperation also bears some hallmarks of Ansoff's development strategies (cf. Ansoff, 1957, p. 35).

2. The Evolutionary School assumes, first of all, that the process of strategy building is conditioned by the organisational culture, the policies of the main coalitions within the organisation, the history, and the influence of the environment, and therefore cannot be fully rational and plannable, according to the assumptions of the planning school (Obłój, 2014, p. 51). Therefore, it treats the organisation's strategy as a coherent model of decisions and actions, evolving in the course of the company's operation (Obłój, 2007, p. 84). In evolutionary terms, the focus is placed on those behaviours and reactions of managers which are the aim or result of adaptation to changing operating conditions (Krupski, Niemczyk, \& Stańczyk-Hugiet, 2009, p. 17).

${ }^{1}$ Comparisons of schools of strategic management with the FTS rationale have been listed in as chronological order as possible according to the formation of subsequent schools. However, this order may be subject to discussion, because it is not possible to clearly indicate the time intervals of the formation of individual schools. 
Convergence with FTS: drawing the attention of the evolutionary school through its deeply empirical character to the previously unnoticed problem of cultural and social conditions of the strategy (Gierszewska \& Romanowska, 2017, p. 14) is extremely close to FTS conditions, both in theory (cf. Gorton \& Motwani, 1996, p. 8; Imtiaz \& Ikram 2016; Mahmood et al., 2017, pp. 2-3;) and in specific case studies (cf. Treinen \& Miller-Frost, 2006; Yap, 2005).

In addition, numerous case studies show the evolutionary process of FTS strategy implementation (cf. Gorton, Hawryszkiewycz, \& Fung, 1996, pp. 80-81; Kroll, Prikladnicki, Audy, Carmel, \& Fernandez, 2013, pp. 3-4; Ramesh \& Dennis, 2002, pp. 3-4) coinciding with the evolutionary trend of strategy approach.

3. The Positioning School, as opposed to the evolutionary approach, does not give up building a strategic plan, but avoids its excessive formalisation characteristic of 'typical planners'. It is not possible to list all the tools of strategic analysis created in this trend, which are today the canon of managerial knowledge. However, the most important assumption of the positional approach is to achieve and maintain a competitive advantage through costs or differentiation. The formulation of the strategy set in the analysis of the company's environment is subordinated to this assumption (Porter, 1980, 1985).

Convergence with FTS: the FTS strategy, the most difficult of those that exploit time zone differences (cf. Carmel \& Espinosa, 2011, p. 58), is at the same time seen as a competitive differentiator allowing to reduce the duration and overall project costs (cf. Treinen \& Miller-Frost, 2006, pp. 1, 12-13). This type of differentiation among other configurations of project teams is a source of competitive advantage (cf. Carmel, 2013, p. 61; Hess \& Audy, 2012, pp. 56, 62; Tang, Zhao, Cao, \& Inkpen, 2011, p. 1;), sought by 'positioners'.

4. The Entrepreneurial School is primarily characterised by visionary, farreaching formulated strategies of true leaders, whose actions and ability to inspire others constitute the majority of the great successes of corporations (Mintzberg, Ahlstrand, \& Lampel, 1998, pp. 136-141).

Convergence with FTS: sharing vision and goals (Espinosa \& Pickering, 2006, pp. 5, 8; Imtiaz \& Ikram, 2016, pp. 2-6), as well as strong management support and leadership that includes valueing achievements, are also key to the effective involvement of employees in 24-hour strategies (Penkala, 1997, pp. 1, 6).

5. The Cultural School defined the strategy formation as a process of social interaction, based on the beliefs and understandings shared by the members of an organization. In addition, it points to specific cultural differences, e.g. between the continents of America, Europe and Asia (Mintzberg et al., 1998, pp. 267-268), relevant to this study.

Convergence with FTS: the FTS literature, in addition to the numerous cultural barriers cited, points to the essence of a culture of highly structured work that includes daily documentation and timely reporting. All members of the organisation, from leaders to project team members, should identify with it (Carmel, \& Espinosa, 
2011, p. 80). Large, mature companies, such as Microsoft, IBM and Siemens, implement cultural standards, related, among others, to the working hours of dispersed project teams ${ }^{2}$ (cf. Imtiaz \& Ikram, 2016, p. 11).

6. The School of Dynamic Capabilities understands the strategy primarily as the development of the capability to dynamically adapt, integrate, or reconfigure resources or competences (Teece, Pisano, \& Shuen, 1997, pp. 515-524).

Convergence with FTS: the capabilities presented above are consistent with the dynamic allocation of FTS tasks (cf. Imtiaz \& Ikram, 2016, pp. 2-6) and the dynamically changing nature of the work ${ }^{3}$. Additionally, the creation of dynamic knowledge repositories, characteristic of FTS (cf. Gupta, 2009, p. 68), intertwines with the school of dynamic capabilities.

7. The Resource School belongs nowadays, next to the planning and positional school, to the group of three most theoretically and empirically established trends in strategic management. It is linked to the planning and positional school by the assumption that building a strategy requires clear managerial choices at corporate level. It is also connected with the evolutionary one by the postulate that the implementation of the strategy is not only of a planned nature, and its implementation is gradual, with the emergence of resources that are of strategic importance from the point of view of the company (Obłój, 2014, pp. 111-112). The triumphant progress of the resource school began with the publication Prahalad and Hamel's 1990 paper, entitled "The Core Competence of the Corporation" (Obłój, 2014, p. 91). In this way, key competences have become the main tool of a resource school.

Convergence with FTS: the appropriate identification of material resources (at least two locations in remote time zones) and intangible resources (e.g. the know-how of knowledge workers) is also essential for FTS strategies. As a result, this should lead to the use of the synergy of resources and the creation of a bundle of key competences enabling cooperation 24 hours a day. Resources are indicated as one of the main criteria for task allocation between remote locations (Mahmood et al., 2017, pp. 1, 6-14).

8. The School of Simple Rules assumes that companies must take advantage of unforeseen and fleeting opportunities to succeed. Effective competition in modern markets requires innovative strategies for taking advantage of opportunities. These are based on several important processes and simple, concrete and easy-to-understand rules to find bottlenecks, and above all to reduce TTM or the time to implement new innovative technology (Eisenhardt \& Sull, 2001, pp. 4, 8).

Convergence with FTS: the shortening of $\mathrm{TTM}^{4}$ which guides the school of simple rules coincides with the sense of FTS strategy. Moreover, clear and simple

2 The cultural standards cited above are implemented both within the companies listed, as well as within the small companies cooperating with them, which must adapt to these standards.

3 This literature touches upon the dynamically changing nature of the GSD work, which also appears in the works of automotive R\&D (cf. Santos, Sales, \& Fernandes, 2012, p. 1, 2015, p. 1; Setamanit, Wakeland, \& Raffo, 2007, pp. 1-3; Shrivastava \& Date, 2010, p. 10).

${ }^{4}$ The author draws attention to the convergence of the main objectives of the School of Simple Rules and FTS, which is to shorten TTM. 
processes, the division of project tasks into as simple as possible, uncomplicated modules, fit into some examples of simple rules. They should make the process of transferring tasks between locations as simple as possible, enabling TTM to be shortened (cf. Carmel \& Espinosa, 2011, pp. 49-50).

9. The Innovation and Entrepreneurial School is described as a set of activities enabling the continuous creation of innovative changes, generating value from the stakeholders' point of view. Its important value is to rely on building innovation, not on the principles of improving the existing states, but on the creative destruction of the existing order and building solutions of the blue ocean type on it (cf. Niemczyk, 2013, pp. 131-132).

Convergence with FTS: using resources in an innovative way which allows to reduce costs by shortening TTM and create new value for the customer, FTS fits into the blue ocean approach. It thus increases the potential for exploiting the so-called innovation gap (Kramer \& Kramer, 1997 as cited in Feldhausen \& Grote, 2013, p. 6), showing additional features in common with the innovation and entrepreneurship approach (cf. Niemczyk, 2013, pp. 131-132).

10. The Network School is described as a set of activities aimed at optimal contract management from the point of view of the stakeholders. An important resource of network organisations are relational resources (Grandori \& Soda, 1996, p. 189), consisting, among others, of acquiring and shaping a network of resources and relationships (also within the company), including the creation and sharing of knowledge in the network with other entities (cf. Niemczyk, 2013, pp. 145-147). Apart from the annuity for the diffusion of tacit knowledge within the network of relations, a characteristic feature of this approach is also the possibility of transferring risk to other entities.

Convergence with FTS: similarly, knowledge sharing and relationships, also interpersonal, are indicated as key to the proper functioning of distributed FTS teams (cf. Espinosa \& Pickering, 2006, pp. 1-9; Kroll et al., 2018, p. 10; Mahmood et al., 2017, pp. 2, 5).

The presented comparisons of the most important premise of FTS against the background of individual schools of strategic management show how much there is in common between the so far not fused scientific fields of science. The final determination of whether FTS is a strategy is presented the next section of the study.

\section{The place of FTS in epistemological categories of strategic management}

When analysing the multitude of strategy definitions, it was notable how many of them refer to the goal that should be achieved (cf. Chandler, 1962, p. 163; Steiner, Miner, \& Gray, 1986, p. 5; Tilles, 1963), and which - in the case of FTS - is also termed in an unambiguous way. Other definitions understand strategy as the creation of a complete plan (cf. Clausewitz, 1976, p. 177; Neumann von \& Morgenstern, 
1944, p. 79), without which the FTS strategy would also be impossible to exist, as well as without defining a sequence of decisions determining behaviour at certain intervals (cf. Simon, 1976, p. 163).

When looking at the most universal criteria for classifying all strategies, a breakdown by aggregation levels is often mentioned (Wit de \& Meyer, 2007, p. 25). Many of the well-known criteria for structuring strategies fall into the behavioural trend. Examples that can be distinguished are the division into deliberate and emerging strategies, proposed by Mitzberg and Waters (1985), and from the viewpoint of the pace of changes (revolutionary and evolutionary) (Greiner, 1972). The criterion of a company's adaptability to changes in the environment by Miles and Miles \& Snow (1978, p. 29), and the criterion based on the general behaviour of an organization in response to changes in the environment defined by Koźmiński and Obłój (1989, pp. 277-284) are among other very popular propositions within the behavioral trend.

From the author's point of view, the above criteria for classifying strategies form the absolute basis among countless classifications. They were cited as important examples of general behavioural strategies relating to the company as a whole that constitute the most basic zero level in the "concept of classifying strategies according to epistemological levels" (Krupski, 2007, pp. 55-59). It is this approach that was chosen to achieve the purpose of this study.

Krupski's proposal, having its roots in one of the main concepts in the general theory of systems (Cavallo \& Klir, 1978; Klir, 1978 as cited in Krupski, 2007, pp. 55-56), offered, unlike others, strict boundary conditions for classifying strategies. These were epistemological levels defined in detail by:

- the characteristics of the basis of its distinction,

- examples of classification of strategies from characteristic (for levels) points of view (Krupski, 2007, pp. 55-59).

At the lowest, zero level of this hierarchy, the system is defined by a set of variables, a set of possible states declared for each variable, and a certain operational form of description of the meaning of both variables and their states, in terms of certain real-world attributes and their manifestations associated with them. For systems at level 0, the term 'source system' was chosen to indicate the desirability of treating this type of system as an experimental data source. Systems at higher epistemological levels differ in their knowledge of the variables of the relevant source system. A higher-level system includes all knowledge available in lower-level systems, as well as some additional knowledge not available at lower levels.

Considering the strategy as a certain system described on the object created by the company's management, it was assumed that the most general content and form of the system is contained in a two-part organisation-environmental arrangement, possibly distinguishing some of the characteristic variables of these elements and their states and/or some basic relations between them. This is part of the Krupski's concept, the previously mentioned zero epistemological level of identification of the 
company strategy. Subsequent levels of higher levels contain the strategy identified in increasingly detailed categories.

The author of the concept rightly notes that there may be some doubts related to the proposed classification of the strategy, and indicates as potentially the largest one the location of behavioural strategies at the most general level 0 , before the subject strategies (domains) which contain the company's objectives (level I). However, it is difficult to disagree with the justification of the proposed order, explained by the fact that the selection of new domains, their change of scope or their removal are determined by the specific attitudes of the decision-makers with subjective and objective reasons. At the same time, Krupski indicated the undoubted existence of feedback between the strategies on both levels (i.e. 0 and I). These are natural in the general theory of systems (Krupski, 2010, pp. 243-244).

From the subject strategies, results the final functional arrangement, which reflects the division of work within the organisation precisely in terms of the objectives covered. Within each of the executive functions, the level II strategies characteristic for them may be adopted.

The level III subject-functional strategies are detailed strategies for the domains and executive functions. Level IV strategies are domain level strategies which are detailed with specific findings of subject-functional strategies. Here there is also some feedback for level III strategies. Last are the competition strategies in detailed domains at level $\mathrm{V}$. Therefore the following six levels are distinguished:

- level 0 - general behavioural strategies for the company as a whole,

- level I - subject-capital strategies,

- level II - functional strategies (place of FTS),

- level III - subject-functional strategies,

- level IV - specific domains strategies,

- level V - competition strategies in specific domains.

As indicated in the above list, the FTS strategy was placed among the functional strategies of the second level of epistemological categories. This choice was made by comparing the FTS characteristics with the characteristics and classification criteria of each of the above mentioned levels. However, due to the editorial limitations ${ }^{5}$, the author provided merely the description of the second level below, as the only one whose assumptions were fully met by the FTS strategy:

The characteristics of level II:

- activities distinguished by the division of executive work within the organisation,

- activities distinguished by their relativisation towards a specific goal or its part. Classification criterion: functional structure of the organization.

Examples:

- marketing strategies,

${ }^{5}$ The volume of the article should be $0.6-0.8$ of the publishing sheet. 
- production strategies,

- R\&D strategies (place of FTS),

- human resources capacity strategies,

- financial strategies.

The second level, characterised by distinguished activities due to the division of executive work in the organisation corresponds to FTS activities, typical for functional R\&D units. The relativisation of these activities to a specific objective or part of it shall in turn correspond to the activities defined to achieve the main objective of the FTS strategy, which is to shorten TTM. In this way, level II assumptions create the most appropriate place in strategic management for the FTS strategy in the title.

\section{Conclusion}

The study presents the basic strategies of time zones and the difference between them. It then shows how often the FTS premise found their place in different schools of strategic management. The most popular strategy definitions and the criteria for classifying them were also indicated.

Ultimately, however, it was the concept of ordering the strategies according to epistemological levels that made it possible to clearly classify FTS among many other functional strategies of R\&D divisions (level II). Moreover, a certain confirmation of the validity of this type of assignment may be an analogous location of the product life-cycle strategy (Krupski, 2010, pp. 241-247). The product lifecycle is a mirror image of the product development cycle on which the FTS strategy is based. Therefore, the answer to the question in the title of this paper should confirm that FTS is a strategy which, as of now, has its basis in strategic management.

Naturally, this study has some research limitations. They consist primarily in the relatively brief mention of the selected strategy definitions and the criteria for classifying the strategy itself. Therefore, in subsequent related studies, the FTS strategy could be further analysed from the point of view of other strategy classification criteria or the definition of the strategy and the attributes it is assigned to.

Bearing in mind that the 'strategy' is defined over time, it might be worth considering when FTS is a functional strategy and when it could become a routine workflow solution. Is it possible, and can higher-level strategies such as corporate or business strategies determine it?

\section{References}

Ansoff, H. I. (1957). Strategies for diversification. Harvard Business Review, (2).

Beulen, E. (2012). I'm working while they're sleeping: what do we still need to learn about outsourcing across time zones? Strategic Outsourcing and International Journal, 5(1), 89-93.

Carmel, E. (2012). The past and future of time zone challenges. Strategic Outsourcing: An International Journal, 5(2), 180-183. 
Carmel, E. (2013). Overcoming your time zone challenges. IESE Insight, March. doi: 10.5581/002

Carmel, E., Dubinsky, Y., \& Johnston, J. M. (2008). Follow the sun-workflow in global software development: Theory, modeling and quasi-experiment to explore its feasibility (Follow the Sun paper for Keystone conference). Retrieved from https://auislandora.wrlc.org/islandora/object/ auislandora3A53355/datastream/PDF/view

Carmel, E., \& Espinosa, A. (2011). I'm working while they're sleeping: Time zone separation challenges and solutions. Nedder Stream Press.

Carmel, E., Espinosa, A., \& Dubinsky, Y. (2010). Follow the sun workflow in global software development. Journal of Management Information Systems, 27(1), 17-38.

Cavallo, R., \& Klir, G. J. (1978). A conceptual foundation for systems problem solving. International Journal of Systems Science, 9.

Chandler, A. D. (1962). Strategy and structure. Cambridge, Mass.: MIT Press.

Clausewitz, C. (1976). On war. Princeton: Princeton University Press.

Doma, S., Gottschalk, L., Uehara, T., \& Liu, J. (2009). Resource allocation optimization for GSD projects. Computational Science and Its Applications (ICCSA), 5593, 13-28.

Eisenhardt, K. M., \& Sull, D. N. (2001). Strategy as simple rules. Harvard Business Review, 79(1).

Espinosa, J. A., \& Pickering, C. (2006). The effect of time separation on coordination processes and outcomes: A case study (Proceedings of the 39th Hawaii International Conference on System Sciences (HICSS'06), pp. 25-35).

Feldhusen, J., \& Grote, K. H. (2013). Pahl/Beitz Konstruktionslehre (8. Auflage). Springer Vieweg.

Gierszewska, G., \& Romanowska, M. (2017). Analiza strategiczna przedsiębiorstwa. Warszawa: Polskie Wydawnictwo Ekonomiczne.

Gorton, I., Hawryszkiewycz, I., \& Fung, L. (1996). Enabling software shift work with groupware: A case study (Proceedings of the 29th Hawaii International Conference on System Sciences, vol. 3, Collaboration Sys.).

Gorton, I., \& Motwani, S. (1996). Issues in co-operative software engineering using globally distributed teams. Information and Software Technology, 38(10), 647-655.

Grandori, A., \& Soda, G. (1996). Inter-firm networks: Antecedents, mechanisms and forms. Organization Studies, (16/2), 183-214.

Greiner, L. E. (1972). Evolution and revolution as organizations grow. Harvard Business Review, (4).

Gupta, A. (2009). The 24-hour knowledge factory: Can it replace the graveyard shift. Computer, 42(1).

Gupta, A., Bondade, R., \& Denny, N. (2008). 24hour knowledge factory: One instance of services computing. Retrieved from https://www.researchgate.net/publication/228217990_24-Hour_ Knowledge_Factory_One_Instance_of_Services_Computing

Gupta, A., Mattarelli, E., Seshasai, S., \& Broschak, J. (2009). Use of collaborative technologies and knowledge sharing in co-located and distributed teams: Towards the 24-h knowledge factory. The Journal of Strategic Information Systems, 18, 147-161.

Gupta, A., \& Seshasai, S. (2007). 24-hour knowledge factory: Using Internet technology to leverage spatial and temporal separations. ACM Trans. Internet Technol., 7, 3.

Hess, E. R., \& Audy, J. L. N. (2012). FTSProc: A process to alleviate the challenges of projects that use the follow-the-sun strategy (Proceedings of the 7th International Conference on Global Software Engineering (ICGSE'12), pp. 56-64).

Imtiaz, S., \& Ikram, N. (2016). Dynamics of task allocation in global software development. J. Software. Evolution and Process, 29(1).

Klir, G. J. (1978). General systems concepts. In R. Trappl (Ed.), Cybernetics: A sourcebook. Washington D.C.: Hemisphere.

Klir, G. J. (2007). General systems concepts. In R. Trappl (Ed.), Cybernetics, a Source-book. Washington D.C.: Hemisphere . 
Koźmiński, A. K., \& Obłój, K. (1989). Zarys teorii równowagi organizacyjnej. Warszawa: PWE.

Kramer, F., \& Kramer, M. (1997). Bausteine der Unternehmensführung. Kundenzufriedenheit und Unternehmenserfolg. Berlin: Springer, Berlin.

Kroll, J., Prikladnicki, R., Audy, J. L. N., Carmel, E., \& Fernandez, J. (2013). A feasibility study of follow-the-sun software development for GSD projects (Proceedings of the International Conference on Software Engineering (SEKE), pp. 196-199).

Kroll, J., Richardson, I., Prikladnicki, R., \& Audy, J. L. N. (2018). Empirical evidence in follow the Sun software development: A systematic mapping study. Information and Software Technology, 93.

Krupski, R. (red.). (2007). Zarządzanie strategiczne. Koncepcje-metody. Wrocław: Akademia Ekonomiczna we Wrocławiu.

Krupski, R. (red.). (2010). Zarządzanie strategiczne. Strategie organizacji. Prace Naukowe Wałbrzyskiej Wyższej Szkoty Zarządzania i Przedsiębiorczości, Seria: Zarządzanie.

Krupski, R., Niemczyk, J., \& Stańczyk-Hugiet, E. (2009). Koncepcje strategii organizacji. Warszawa: PWE.

Mahmood, S., Anwer, S., Niazi, M., Alshayeb, M., \& Richardson I. (2017). Key factors that influence task allocation in global software development. Information and Software Technology, (91), 102-122.

Miles, R. E., \& Snow, C. C. (1978). Organizational strategy, structure, and process. New York: McGraw-Hill.

Mintzberg, H., Ahlstrand, B., \& Lampel, J. (1998). Strategy safari. A guided tour through the wilds of strategic management. New York: The Free Press.

Mintzberg, H., \& Waters, J. A. (1985). Of strategies: deliberate and emergent. Strategic Management Journal, (3).

Neumann, J. von, \& Morgenstern, P. (1944). Theory of games and economic behaviour. Princeton: Princeton University Press.

Niemczyk, J. (2013). Strategia. Od planu do sieci. Wrocław: Wydawnictwo UE we Wrocławiu.

Obłój, K. (2007, 2014). Strategia organizacji. Warszawa: PWE.

Penkala, D. (1997). Improving productivity and profitability round the clock. National Productivity Review, CCC 0277-8556/97/1603029-07.

Porter, M. E. (1980). Competitive strategy - techniques for analysing industries and competitors. New York: The Free Press.

Porter, M. E. (1985). Competitive advantage - creating and sustaining superior performance. New York: The Free Press.

Ramesh, V., \& Dennis, A. (2002). The object oriented team: Lessons for virtual teams from global software development (Proceedings of the 35th Annual Hawaii International Conference on System Sciences (HICSS'02), vol. 1, p. 18).

Santos, A. R., Sales, A, \& Fernandes, P. (2012). Setting up a stochastic model for teams working in a Follow-the-Sun environment (Proceedings of the 7th International Conference on Global Software Engineering (ICGSE), p. 179).

Santos, A. R., Sales, A., \& Fernandes, P. (2015). Using SAN formalism to evaluate Follow-The-Sun project scenarios. Journal of Systems and Software, 100, 182-194.

Serwiński, M. (2019a). Identification of the optimal automotive R\&D area in the context of implementing of the Follow-the-Sun strategy - empirical study. Research Papers of the Wroclaw University of Economics, 63(7), 286-298.

Serwiński, M. (2019b). Wykorzystanie stref czasowych we współpracy jednostek R\&D sektora automotive. In P. Antonowicz, E. Malinowska, \& J. Siciński (red.), Sektorowe uwarunkowania funkcjonowania i rozwoju przedsiębiorstw. Gdańsk: Wydawnictwo Uniwersytetu Gdańskiego. 
Setamanit, S., Wakeland, W., \& Raffo, D. (2006). Exploring the impact of task allocation strategies for global software development using simulation (Proceedings (LNCS 3966), pp. 274-285). Berlin, Heidelberg: Springer.

Setamanit, S., Wakeland, W., \& Raffo, D. (2007). Using simulation to evaluate global software development task allocation strategies. Software. Process: Improve. Practice, 12, 491-503.

Shrivastava, S. V., \& Date, H. (2010). Distributed agile software development: A review. Journal of Computer Science and Engineering, 1(1).

Simon, H. A. (1976). Działanie administracji. Warszawa: PWN.

Smith, P. G., \& Reinersten, D. G. (1991). Developing products in half the time. New York: Van Nostrand Reinhold.

Steiner, G. A., Miner, J. B., \& Gray, E. (1986). Management policy and strategy ( ${ }^{\text {rd }}$ ed.) New York: Macmillan Publ.

Tang, J. C., Zhao, C., Cao, X, \& Inkpen, K. (2011). Your time zone or mine?: A study of globally time zone-shifted collaboration (Proceedings of the ACM 2011 Conference on computer Supported Cooperative Work (CSCW'11), pp. 235-244).

Teece, D., Pisano, G., \& Shuen, A. (1997). Dynamic capabilities and strategic management. Strategic Management Journal, 18(7).

Tilles, S. (1963). How to evaluate corporate strategy. Harvard Business Review, July.

Treinen, J. J., \& Miller-Frost, S. L. (2006). Following the Sun: Case studies in global software development. IBM Systems Journal. 45(4).

Wit, B. de, \& Meyer, R. (2007). Synteza strategii. Warszawa: PWE.

Yap, M. (2005). Follow the Sun: Distributed extreme programming development. (Agile Conference Proceedings, pp. 218-224).

\section{FOLLOW-THE-SUN - CZY TO NA PEWNO STRATEGIA Z PERSPEKTYWY ZARZĄDZANIA STRATEGICZNEGO?}

Streszczenie: Artykuł jest odpowiedzią na problem poruszony przez E. Beulena (2012), dotyczący stref czasowych oraz strategii, które nie zostały połączone w literaturze dotyczącej zarządzania lub outsourcingu. „Pojawiły się pewne teoretyczne przemyślenia na temat wpływu stref czasowych na planowanie, ale nie na strategię" (Carmel, 2012, s. 2). Przedmiotem analiz jest strategia Follow-the-Sun (FTS), będąca najtrudniejszą spośród tych, które wykorzystują różnice stref czasowych (por. Carmel \& Espinosa, 2011, s. 58). Jej głównym celem jest dalsze zwiększanie tempa prac B+R poprzez wykorzystanie zespołów projektowych rozproszonych w odległych strefach czasowych, zdolnych do zapewnienia 24-godzinnego cyklu pracy bez konieczności wykonywania jej w nocy (Serwiński, 2019a, s. 1). Celem głównym publikacji jest z kolei przedstawienie konkretnej propozycji klasyfikowania strategii FTS w zarządzaniu strategicznym.

Słowa kluczowe: Follow-the-Sun, czas powstawania produktu, zarządzanie strategiczne, motoryzacja, strefy czasowe. 